\title{
ANTARA UANG PENGGANTI DAN KERUGIAN NEGARA DALAM TINDAK PIDANA KORUPSI ${ }^{1}$
}

\author{
Kristwan Genova Damanik \\ Pengadilan Tinggi Maluku Utara \\ Jalan Cengkeh Afo, No. 16 Ternate \\ Email: dkristwan@yahoo.com;kgdamanik59@gmail.com
}

\begin{abstract}
The purpose of this research was to determine the meaning of compensation and state's damage of corruption; and to determine the application of the law for compensation for losses in the state of corruption whether it is appropriate and in accordance with the principle of legal certainty and justice. The method used is normative. The results showed Compensation is money paid by the defendant property "acquired or enjoyment" of corruption and not for losses to the state caused. The application of the law to declare losses to the state as compensation to be paid based on the defendant without evidence is injure legal certainty and justice and human rights, and an error in the application of the law.
\end{abstract}

Keywords: Compensation; Corruption; State Losses.

\begin{abstract}
Abstrak
Tujuan penelitian ini adalah untuk mengetahui makna uang pengganti dan kerugian negara dalam tindak pidana korupsi; dan untuk mengetahui penerapan hukum pembayaran uang pengganti sebesar kerugian negara dalam tindak pidana korupsi apakah sudah tepat dan sesuai dengan asas kepastian hukum dan keadilan. Metode yang digunakan adalah yuridis normatif. Hasil penelitian menunjukkan Uang pengganti adalah uang yang dibayar terdakwa sebesar harta benda yang "diperoleh atau dinikmatinya" dari tindak pidana korupsi, bukan sebesar kerugian negara yang ditimbulkannya. Penerapan hukum untuk menyatakan kerugian negara sebagai uang pengganti yang harus dibayar terdakwa tanpa didasarkan pada alat bukti adalah mencederai asas kepastian hukum dan keadilan serta hak asasi, dan merupakan kesalahan dalam penerapan hukum.
\end{abstract}

Kata Kunci: Uang Pengganti; Tindak Pidana Korupsi; Kerugian Negara.

\section{A. Pendahuluan}

1. Latar Belakang Permasalahan

Tindak pidana korupsi di Indonesia dari tahun ke tahun mengalami peningkatan jumlah kasusnya, kerugian negaranya, dan kualitas cara melakukannya, berikut dengan ulasan dan kritik dari berbagai elemen di media massa, bagaikan tiada hari tanpa tindak pidana korupsi. Seiring dengan meningkatnya tindak pidana korupsi tersebut, wacana pemberantasannya semakin mengemuka sejak era reformasi yang akhirnya menjadi tema sentral dalam penegakan hukum di Indonesia. Berbagai upaya dan strategi telah dilakukan untuk memberantas tindak pidana korupsi, termasuk upaya pencegahannya, namun korupsi semakin menjamur dan berkembang seiring dengan hingar-bingarnya pemberitaan di media massa.

Semaraknya tindak pidana korupsi tersebut menimbulkan perubahan rumusan delik korupsi. Perubahan tersebut tidak dapat dipisahkan dari kebijakan pemerintah yang lebih luas dalam menetapkan suatu kebijakan di bidang hukum pidana dalam rangkaian usaha pemberantasan tindak pidana korupsi, mengingat modus operandi tindak pidana korupsi mengalami perkembangan yang cepat seiring dengan perkembangan teknologi, ${ }^{2}$ karena perkembangan masyarakat

1.Artikel ini merupakan hasil penelitian.

2.I.K. Rai Setiabudhi, 2016, Peran Masyarakat Sipil dalam Pemberantasan Korupsi: Model Pencegahan dari Bali,

Demi Keadilan, Antologi Hukum Pidana dan Sistem Peradilan Pidana, Jakarta, Pustaka Kemang, hlm.152. 
demikian cepat dan modus operandi tindak pidana korupsi semakin canggih dan variatif di satu pihak, sedangkan perkembangan hukum ("law in book") relatif tertinggal dengan perkembangan masyarakat di pihak lain. ${ }^{3}$

Dalam mewujudkan pemerintahan yang bersih, pemberantasan korupsi merupakan salah satu prioritas demi mewujudkan masyarakat adil, makmur, dan sejahtera. Dikatakan sebagai prioritas, karena korupsi telah merasuki lini kehidupan masyarakat Indonesia, sehingga pola penanganannya pun memerlukan cara khusus. Selain itu, mengingat korupsi merupakan kejahatan terorganisir yang dilakukan secara sistematis, terkait dengan kekuasaan, serta terkait pula dengan nasib orang banyak karena adanya keuangan negara yang dirugikan, maka tepat untuk menggolongkan tindak pidana korupsi sebagai tindak pidana khusus. ${ }^{4}$

Penjelasan Umum UU Tipikor menyebutkan bahwa keuangan negara adalah seluruh kekayaan negara dalam bentuk apapun, yang dipisahkan atau yang tidak dipisahkan, termasuk di dalamnya segala bagian kekayaan negara dan segala hak dan kewajiban yang timbul karena: (a) berada dalam penguasaan, pengurusan dan pertanggungjawaban pejabat lembaga Negara, baik di tingkat pusat maupun di daerah; dan (b) berada dalam penguasaan, pengurusan dan pertanggungjawaban Badan Usaha Milik Negara/Badan Usaha Milik Daerah, yayasan, badan hukum, dan perusahaan yang menyertakan modal negara, atau perusahaan yang menyertakan modal pihak ketiga berdasarkan perjanjian dengan negara. Sedangkan, yang dimaksud dengan Perekonomian Negara adalah kehidupan perekonomian yang disusun sebagai usaha bersama berdasarkan asas kekeluargaan ataupun usaha masyarakat secara mandiri yang didasarkan pada kebijakan Pemerintah, baik di tingkat pusat maupun di tingkat daerah sesuai dengan ketentuan peraturan perundang-undangan yang berlaku yang bertujuan memberikan manfaat, kemakmuran dan kesejahteraan kepada seluruh kehidupan rakyat.

Penyebutan keuangan negara dalam UU Tipikor tersebut menimbulkan konsekuensi bahwa UU Tipikor tidak dapat dipisahkan dari keterkaitannya dengan undang-undang yang mengatur keuangan negara (UU Nomor 17 Tahun 2003 tentang Keuangan Negara). Dalam UU Tipikor tidak tercantum pengertian tentang kerugian negara, namun dalam Pasal 1 angka 22 UU Nomor 1 Tahun 2004 tentang Perbendaharaan Negara disebutkan bahwa kerugian negara haruslah sudah nyata-nyata ada atau terjadi dan pasti jumlahnya. Perihal kerugian negara, dalam praktik persidangan, seringkali Penuntut Umum dalam tuntutannya menyebutkan kerugian negara yang telah dihitung $\mathrm{BPKP} / \mathrm{BPK}$ merupakan uang pengganti yang harus dibayar terdakwa. Penuntut Umum tentunya tidak boleh secara serampangan menentukan jumlah uang pengganti hanya didasarkan penghitungan BPKP/BPK, tanpa melihat ketentuan Pasal 18 Ayat (1) huruf b UU Tipikor. Sebagaimana disebutkan Eddy O.S Hiariej, jaksa penuntut umum (dan juga aparat penegak hukum yang lain) merupakan salah satu unsur dari enam unsur yang perlu diperhatikan dalam mewujudkan putusan pengadilan tindak pidana korupsi yang baik, dalam arti disamping menjamin kepastian hukum, juga harus adil dan bermanfaat. ${ }^{5}$

Berdasarkan uraian di atas, maka penulis tertarik melakukan penelitian mengenai: (a) apakah uang pengganti sama dengan kerugian negara dalam tindak pidana korupsi?; dan (b) apakah penerapan hukum pembayaran uang pengganti sebesar kerugian negara dalam tindak pidana korupsi sudah tepat dan sesuai dengan asas kepastian hukum dan keadilan?

\section{Metode Penelitian}

Metode penelitian yang digunakan dalam penelitian ini adalah yuridis normatif, yaitu pendekatan melalui peraturan perundang-undangan yang terkait dengan uang pengganti dan kerugian negara,

3. Lilik Mulyadi, 2007, Tindak Pidana Korupsi di Indonesia, Normatif, Teoritis, Praktik dan Masalahnya, Bandung, Cet. 1, Alumni, hlm.3.

4.Eddy O.S. Hiariej, 2016, Eksistensi Komisi Pemberantasan Korupsi, Demi Keadilan, Antologi Hukum Pidana dan Sistem Peradilan Pidana, Jakarta, Pustaka Kemang, hlm. 132.

5. Eddy O.S Hiariej, "Menyoal Putusan Pengadilan Tipikor”, Jurnal Masalah-Masalah Hukum, Vol. 42, No. 1, Januari 2013, hlm. 60-61. 
khususnya UU Tipikor, UU Nomor 1 Tahun 2004 tentang Perbendaharaan Negara, UU Nomor 15 Tahun 2006 tentang Badan Pemeriksa Keuangan (BPK), Putusan Mahkamah Agung dan Pasal 1365 KUH Perdata tentang perbuatan melawan hukum.

\section{Kerangka Teori \\ a. Penegakan Hukum dalam Negara Hukum}

Proses penegakan hukum tidak terlepas dari aturan hukum maupun para penegak hukumnya. Aturan hukum dalam negara hukum menjadi sarana terciptanya penegakan hukum yang andal, di mana integritas para penegak hukum juga merupakan modal utama untuk tercapainya keadilan sebagai salah satu tujuan akhir dari hukum. Aturan hukum yang baik tanpa penegak hukum yang paham akan mengakibatkan tidak sesuainya antara proses hukum yang berlangsung dengan maksud dibentuknya peraturan hukum itu sendiri. Penegakan hukum yang benar dan adil tidak semata-mata ditentukan oleh kehendak pelaku hukum sebagai "ratu adil", tetapi juga kemauan dan kemampuan masyarakat untuk berupaya memperoleh perlakuan hukum yang adil dan benar. Dengan perkataan lain, penegakan hukum yang adil ditentukan juga oleh kesadaran dan partisipasi masyarakat, bukan semata-mata keinginan penegak hukum. ${ }^{6}$

Negara hukum menurut Arief Sidharta adalah negara yang berintikan unsur-unsur dan asas-asas dasar sebagai berikut: ${ }^{7}$

1) Pengakuan, penghormatan, dan perlindungan kepribadian manusia yang mengimplikasikan atas pengakuan dan perlindungan martabat dan kebebasan manusia, yang merupakan asas fundamental negara hukum;

2) Asas kepastian hukum, di mana pemerintah dan para pejabatnya harus bebas dari tindakan yang tidak dapat diprediksi dan tindakan yang sewenangwenang dan terikat dan tunduk pada aturan hukum positif;
3) Asas persamaan, di mana pemerintah dan para pejabatnya harus memberikan perlakuan sama kepada semua orang dan undang-undang juga berlaku sama untuk semua orang;

4) Asas demokrasi, yaitu berkenaan dengan cara mengambil keputusan, di mana setiap warganegara memiliki kemungkinan dan kesempatan yang sama untuk mempengaruhi keputusan dan tindakan pemerintah; dan

5) Asas pemerintah dan para pejabatnya mengemban fungsi melayani rakyat, di mana pemerintah harus menata tiap tindakannya secara bertujuan dan berhasil guna serta mengacu pada kepentingan umum.

Dengan ciri negara hukum sebagaimana diuraikan di atas dalam kaitannya dengan penegakan hukum, masyarakat mendapat perlindungan dari pemerintah dan para pejabatnya; di sisi lain, pemerintah dan para pejabatnya menjalankan tugas sebagaimana koridor yang telah ditetapkan dengan tidak sewenang-wenang (otoriter).

\section{b. Asas Kepastian Hukum}

Asas kepastian hukum adalah asas dalam negara hukum yang mengutamakan landasan peraturan perundang-undangan, kepatutan, dan keadilan dalam setiap kebijakan penyelenggara negara. ${ }^{8}$ Asas kepastian hukum menghendaki konsistensi penyelenggaraan hukum. Kepastian hukum dalam kehidupan berbangsa, bernegara, dan bermasyarakat merupakan tujuan dari negara hukum. Oleh karena itu, hukum bertujuan mewujudkan kepastian dalam hubungan antar manusia berupa menjamin prediktabilitas dan mencegah dominasi hak pihak yang terkuat. Unsur kepastian hukum dalam penegakan hukum merupakan perlindungan bagi yustisiabelen atas tindakan seseorang terhadap orang lain, karena hukum dianggap sebagai rujukan terakhir mengatasi konflik yang terjadi dalam masyarakat. ${ }^{9}$

Budiono Kusumohamidjojo

6. Bagir Manan, 2015, Sistem Peradilan Berwibawa (Suatu Pencarian), Jakarta, Mahkamah Agung RI, hlm. 8.

7. Bernard Arief Sidharta, 1999, Refleksi tentang Struktur Hukum, Sebuah penelitian tentang fundasi kefilsafatan dan sifat keilmuan Ilmu Hukum sebagai landasan pengembangan Ilmu Hukum nasional Indonesia, Bandung, Mandar Maju, hlm. 199.

8. Dwidja Priyatno, 2012, Kriminalisasi Kebijakan, Wajah Hukum Pidana, Asas dan Perkembangannya, Jakarta, Gramata, hlm.10.

9. A. Ahsin Thohari, "Dari Law Enforcement ke Justice Enforcement", Harian KOMPAS, 3 Juli 2002, hlm. 31. 
mengatakan penyelenggaraan hukum yang tidak konsisten tidak akan membuat masyarakat mau mengandalkannya sebagai perangkat kaidah yang mengatur kehidupan bersama. Konsistensi dalam penyelenggaraan hukum itulah yang disebut kepastian hukum. Konsistensi itu diperlukan sebagai acuan bagi perilaku manusia sehari-hari dalam berhubungan dengan manusia lainnya. Arief Sidharta mengatakan bahwa asas kepastian hukum mengimplikasikan bahwa warga masyarakat harus bebas dari tindakan pemerintah dan pejabatnya yang tidak dapat diprediksi dan tindakan yang sewenangwenang. Pemerintah dan para pejabatnya harus terikat dan tunduk pada aturan hukum positif. Semua tindakan pemerintah dan para pejabatnya harus selalu bertumpu pada aturan hukum positif sebagai dasar hukumnya. ${ }^{11}$

Menurut Mochtar Kusumaatmadja, asas kepastian hukum harus diimplementasikan dan ditegakkan dalam kehidupan berbangsa, bernegara, dan bermasyarakat. Pengimplementasian asas kepastian hukum menuntut dipenuhinya beberapa syarat, antara lain peraturan perundang-undangan hanya mengikat warga masyarakat setelah diundangkan dan tidak memiliki daya berlaku surut (nonretroaktif). Dengan diterapkannya asas kepastian hukum, maka salah satu tujuan hukum telah terakomodasi dalam kehidupan negara hukum.

\section{c. Asas Keadilan}

Hukum tidak dapat dilepaskan dari keadilan, mengingat salah satu tujuan hukum adalah keadilan, tetapi harus diingat bahwa hukum tidak identik dengan keadilan karena hukum bersifat umum, mengikat setiap orang, dan bersifat menyamaratakan atau tidak membeda-bedakan keadaan, status, ataupun perbuatan yang dilakukan oleh manusia. Bagi hukum, setiap kejahatan oleh pelaku tindak pidana atau pelanggaran hukum oleh para pihak yang berperkara akan dijatuhkan pidana/hukuman yang sesuai dengan apa yang tertera dalam bunyi pasal undangundang, sehingga keadilan menurut hukum belum tentu sama dengan keadilan moral atau keadilan masyarakat.13

Dalam pandangan Thomas Hobbes, keadilan tidak berhubungan dengan aspek batin manusia, melainkan lebih menitikberatkan pada perbuatan-perbuatan manusia, yaitu terutama mengatur perilaku manusia. Dalam pemikiran ini pula, yang dimaksud persamaan derajat adalah kesamaan hak berdasarkan keberlakuan hukum dan kesamaan dalam konteks keharusan moral. ${ }^{14}$ Dengan adanya kesamaan derajat di antara sesama dalam pergaulan hidup, maka perilaku dan perbuatan manusia akan menjadi ukuran bagi hukum untuk bertindak demi menciptakan keadilan, sehingga pada akhirnya prinsip keadilan, yakni memberikan kepada seseorang apa yang menjadi haknya, dapat terwujud.

\section{d. Uang Pengganti}

Uang pengganti sudah dikenal pada tahun 1960 melalui Perpu Nomor 24 Tahun 1960 tentang Pengusutan, Penuntutan, dan Pemeriksaan Tindak Pidana Korupsi, yaitu dalam Pasal 16 ayat (3), bahwa terhukum dapat juga diwajibkan membayar uang pengganti yang jumlahnya sama dengan harta benda yang diperoleh dari korupsi. Setelah Perpu Nomor 24 Tahun 1960 diganti dengan UU Nomor 3 Tahun 1971, ketentuan tentang uang pengganti tetap diatur dengan rumusan yang sama, yakni dalam Pasal 34 ayat (3). Demikian pula halnya dalam UU Tipikor, ketentuan uang pengganti diatur dalam Pasal 18 ayat (1) hurufb.

Pasal 18 ayat (1) huruf b UU Tipikor menyebutkan bahwa pembayaran uang pengganti yang jumlahnya sebanyakbanyaknya sama dengan harta benda yang diperoleh dari tindak pidana korupsi. UU Tipikor maupun Penjelasannya tidak mengatur pengertian uang pengganti. Pasal 18 ayat (1) huruf b UU Tipikor hanya menyebutkan keterkaitan antara uang pengganti dengan harta benda yang "diperoleh" dari tindak pidana korupsi.

Menurut Komariah Emong Sapardjaja,

\footnotetext{
11. Budiono Kusumohamidjojo, 1999, Ketertiban Yang Adil: Problematik Filsafat Hukum, Jakarta, Grasindo, hlm. 150. 12. Bernard Arief Sidharta, Op. Cit., hlm. 200.

Ibid.

13.Ahmad Rifai, 2010, Penemuan Hukum oleh Hakim dalam Perspektif Hukum Progresif, Jakarta, Sinar Grafika, hlm. 131.

14. Ibid., hlm. 182.
} 
uang pengganti adalah uang yang benar-benar "dinikmati" terdakwa dari hasil tindak pidana korupsi yang dilakukannya dan jumlahnya harus jelas. Salman Mariadi berpendapat bahwa uang pengganti adalah uang yang harus dibayar oleh orang yang menikmatinya dan sifatnya hanya penggantian atas apa yang telah dipergunakannya, sehingga tidak dikenal istilah "renteng" dalam pembayaran uang pengganti 16 Sementara itu, Iskandar Kamil berpendapat uang pengganti tidak bisa direnteng karena tangggung jawab renteng merupakan klausula dalam hukum perdata, sedangkan tanggungjawab pidana merupakan tanggung jawab individu, sehingga bila uang pengganti tidak dapat dihitung/dibuktikan secara jelas jumlahnya, maka tidak bisa dihukum. ${ }^{17}$

Lain lagi halnya bila merujuk pada putusan hakim Pengadilan Negeri Jakarta Selatan No.970/Pid.B/2009/PN Jkt.Sel tanggal 4 Nopember 2009, uang pengganti ditafsirkan lebih luas dari pengertian uang pengganti sebagaimana dimaksud dalam UU Tipikor. Di dalam pertimbangan hukumnya disebutkan, karena unsur "memperkaya diri sendiri terbukti", dan terdakwa selaku Direktur Utama PT. SRD menerima gaji imbalannya setiap bulan dari tahun $2000 \mathrm{~s} / \mathrm{d}$ Nopember 2008 sebesar Rp.3.560.000.000,(tiga miliar lima ratus enam puluh juta rupiah), maka menjatuhkan uang pengganti sebesar gaji yang telah diterimanya tersebut sebesar Rp.3.560.000.000,- . (tiga miliar lima ratus enam puluh juta rupiah).

Penulis tidak sependapat dengan pertimbangan hakim perihal uang pengganti yang dikenakan terhadap terdakwa tersebut, mengingat gaji yang diterima terdakwa tidak ada kaitan hukumnya dengan tindak pidana korupsi yang dilakukannya dan merupakan tindakan semena-mena dan bertentangan dengan nilai-nilai keadilan, sebagaimana juga yang dinyatakan Chairul Huda bahwa putusan Pengadilan Negeri Jakarta Selatan
No.970/Pid.B/2009/PN Jkt.Sel tanggal 4 Nopember 2009 tersebut telah "merampas hak-hak hakiki" dari seseorang yang membaktikan diri untuk keluarganya, karena hak seseorang berupa gaji diperoleh sah yang dilindungi oleh konstitusi (Pasal 28D ayat (2) UUD 1945), Undang-undang Perseroan Terbatas (Pasal 96 ayat 1 UU No.40 Tahun 2007) dan Undang-undang Ketenagakerjaan (Pasal 1 angka 30 jo. Pasal 88 ayat $1 \mathrm{UU}$ No.13 tahun 2003). ${ }^{18}$

Penulis sependapat dengan Komariah Sapardjaja, Salman Mariadi dan Iskandar Kamil bahwa uang pengganti adalah sebesar yang dinikmatinya, mengingat asas hukum bahwa seseorang bertanggungjawab sebesar apa yang telah dinikmati / diperolehnya, bukan atas dasar gaji yang diperolehnya yang tidak ada kaitannya dengan tindak pidana sebagaimana dinyatakan Chairul Huda.

\section{e. Kerugian Negara}

Dalam Pasal 1 angka 15 UU Nomor 15 Tahun 2006 tentang Badan Pemeriksa Keuangan disebutkan bahwa kerugian negara/daerah adalah kekurangan uang, surat berharga, dan barang yang nyata dan pasti jumlahnya sebagai akibat perbuatan melawan hukum, baik sengaja maupun lalai. Pengertian kerugian negara tersebut diuraikan juga dalam Pasal 1 angka 22 UU Nomor 1 Tahun 2004 tentang Perbendaharaan Negara dengan definisi yang sama. Penjelasan Pasal 32 ayat (1) UU Tipikor disebutkan bahwa yang dimaksud dengan secara nyata telah ada kerugian negara adalah kerugian negara yang sudah dapat dihitung jumlahnya berdasarkan hasil temuan instansi yang berwenang atau akuntan publik yang ditunjuk. Lilik Mulyadi menyebutkan perbuatan kerugian tersebut secara sederhana dapat disebutkan sebagai perbuatan yang mengakibatkan menjadi rugi atau menjadi berkurang, sehingga unsur "merugikan keuangan negara" diartikan sebagai menjadi ruginya keuangan negara atau berkurangnya keuangan negara. ${ }^{19}$ Pengertian keuangan

\footnotetext{
15. Komariah Emong Sapardjaja (Hakim Agung), 15 April 2008, Ceramah pada Pelatihan Hakim Tipikor Angkatan II, Ciloto, Bogor.

16. Salman Mariadi (Direktur Penuntutan Pidana Khusus Kejagung RI), 16 April 2008, Ceramah pada Pelatihan Hakim Tipikor Angkatan II, Ciloto, Bogor.

17. Iskandar Kamil (Hakim Agung), 25 April 2008, Ceramah pada Pelatihan Hakim Tipikor Angkatan II, Ciloto, Bogor.

18. Chairul Huda, "Menyoal Pidana Tambahan "Pembayaran Uang Pengganti" Dalam Perkara Korupsi", tersedia di website http://huda-chairulhudashmh.blogspot.com, diakses pada tanggal 10 Juni 2015.

19. Lilik Mulyadi, Op. Cit., hlm. 89.
} 
negara diatur di dalam UU Nomor 17 Tahun 2003 tentang Keuangan Negara, yaitu semua hak dan kewajiban negara yang dapat dinilai dengan uang, serta segala sesuatu, baik berupa uang maupun berupa barang, yang dapat dijadikan milik negara berhubung dengan pelaksanaan hak dan kewajiban tersebut.

\section{B. Hasil dan Pembahasan}

\section{Makna Uang Pengganti sebagai Pidana Tambahan}

Dalam KUHP diatur perihal pidana pokok dan pidana tambahan, tepatnya dalam Pasal 10, yang menyebutkan pidana pokok meliputi pidana mati, pidana penjara, pidana kurungan, pidana denda maupun pidana tutupan, dan pidana tambahan. Sementara itu, dalam UU Tipikor juga dikenal pidana pokok, berupa pidana mati, pidana penjara, dan pidana tambahan.

Pidana tambahan dalam KUHP meliputi pencabutan hak-hak tertentu, perampasan barang-barang tertentu, dan pengumuman putusan hakim, sedangkan pidana tambahan dalam Pasal 18 ayat (1) UU Tipikor meliputi:

a. Perampasan barang bergerak yang berwujud atau yang tidak berwujud atau barang tidak bergerak yang digunakan untuk atau yang diperoleh dari tindak pidana korupsi, termasuk perusahaan milik terpidana di mana tindak pidana dilakukan, begitu pula harga dari barang yang menggantikan barangbarang tersebut;

b. Pembayaran uang pengganti yang jumlahnya sebanyak-banyaknya sama dengan harta benda yang diperoleh dari tindak pidana korupsi;

c. Penutupan seluruh atau sebagian perusahaan untuk paling lama 1 (satu) tahun; dan

d. Pencabutan seluruh atau sebagian hakhak tertentu atau penghapusan seluruh atau sebagian keuntungan tertentu, yang telah atau dapat diberikan oleh pemerintah kepada terpidana.

Pidana tambahan dijatuhkan apabila terdapat keterkaitan pelaku tindak pidana dengan barang yang menjadi obyek tindak pidana, seperti keterkaitan dengan barang yang diperoleh atau digunakan dalam melakukan tindak pidana korupsi, keterkaitan dengan harta yang diperoleh dari tindak pidana korupsi, maupun keterkaitan dengan perusahaan yang menjadi bagian dalam tindak pidana korupsi. Pidana tambahan sifatnya mengikuti pidana pokok, dalam arti pidana tambahan tidak bisa berdiri sendiri tanpa adanya pidana pokok yang mengikutinya, sehingga sifatnya imperatif. ${ }^{20}$

Berkaitan dengan pidana tambahan berupa uang pengganti, hakim berpedoman pada Pasal 18 ayat (1) huruf b UU Tipikor, di mana besarnya uang pengganti adalah sebesar harta benda yang diperoleh dari tindak pidana korupsi yang dilakukannya. Uang pengganti dinyatakan sebagai pidana tambahan, karena uang pengganti sifatnya mengikuti pidana pokok, di mana dengan terbukti melakukan perbuatan yang merugikan negara, maka segala harta yang diperoleh dari tindak pidana korupsi ditarik kembali sebagai uang pengganti dengan tujuan agar apa yang telah dinikmatinya, dikembalikan kepada negara selaku subyek yang dirugikan. Menurut Fontian Munzil dkk perhitungan kerugian uang negara harus dihitung secara rinci dengan mempertimbangkan rentang waktu sampai dengan uang negara tersebut dapat dikembalikan oleh terpidana korupsi. ${ }^{21}$

\section{Penerapan Hukum Pembayaran Uang Pengganti sebagai Kerugian Negara}

Oleh karena hukum menyandang tujuan untuk mewujudkan ketertiban dan keadilan secara konkret dalam masyarakat, maka dalam hukum terkandung kecenderungan konservatif (mempertahankan dan memelihara apa yang sudah dicapai) maupun kecenderungan modernis (membawa, mengkanalisasi, dan mengarahkan perubahan). Dalam hal suatu peraturan tidak diatur atau tidak jelas maksud dan arahnya, diperlukan pemecahan masalah dengan menemukan sendiri hukum yang tepat untuk mengatasi kekuranglengkapan melalui berbagai sumber hukum lain, seperti

\footnotetext{
20.Andi Hamzah, 1994, Asas-asas Hukum Pidana, Edisi Revisi, Jakarta, Rineka Cipta, hlm.191.

Fontian Munzil, Imas Rosidawati Wr, dan Sukendar, "Kesebandingan Pidana Uang Pengganti dan Pengganti Pidana

21.Uang Pengganti dalam Rangka Melindungi Hak Ekonomis Negara dan Kepastian Hukum", Jurnal Hukum IUS QUIA 22. IUSTUM, Vol. 22, No.1, Januari 2015, hlm. 32.

Bernard Àrief Sidharta, Op. Cit., hlm.116. 
yurisprudensi, doktrin, traktat, kebiasaan, atau hukum tidak tertulis lainnya (rechtsvinding).

Ketentuan Pasal 18 ayat (1) UU Tipikor tentang pidana tambahan di atas, tepatnya pada huruf $b$, tidak menyebutkan pengertian uang pengganti. Namun, bila pengertian "diperoleh" sebagaimana acuan KBBI dikaitkan dengan pendapat Komariah Emong Sapardjaja, maka pengertian uang pengganti yang "diperoleh" terdakwa mengandung arti sebagai harta benda yang "didapat" dan "dinikmati" terdakwa dari usahanya melakukan korupsi.

Memperhatikan ketentuan Pasal 18 ayat (1) huruf b UU Tipikor, maka uang pengganti dibebankan kepada yang bersangkutan hanya sebesar uang yang diperolehnya dari tindak pidana korupsi. Ketentuan tersebut tidak menyinggung tentang besarnya kerugian negara, sehingga uang pengganti tidak ada kaitannya dengan besarnya kerugian negara. Dengan demikian, maksud dan tujuan diterapkannya uang pengganti sebagai hukuman tambahan adalah bukan untuk mengembalikan kerugian negara atau memulihkan besarnya kerugian negara, tetapi semata-mata untuk merampas keuntungan yang diperoleh dari perbuatan yang dilakukannya.

Demikian pula halnya dengan kerugian negara, Pasal 1 angka 15 UU Nomor 15 Tahun 2006 tentang Badan Pemeriksa Keuangan dan Pasal 1 angka 22 UU Nomor 1 Tahun 2004 tentang Perbendaharaan Negara menyebutkan kerugian negara/daerah adalah kekurangan uang, surat berharga, dan barang yang nyata dan pasti jumlahnya sebagai akibat perbuatan melawan hukum, baik sengaja maupun lalai. Penjelasan Pasal 32 ayat (1) UU Tipikor menyatakan, yang dimaksud dengan secara nyata telah ada kerugian negara adalah kerugian yang sudah dapat dihitung jumlahnya berdasarkan hasil temuan instansi yang berwenang atau akuntan publik yang ditunjuk. Demikian pula Lilik Mulyadi menyebutkan bahwa perbuatan tersebut harus mengakibatkan menjadi rugi atau menjadi berkurang, sehingga unsur merugikan keuangan negara diartikan sebagai menjadi ruginya keuangan negara atau berkurangnya keuangan negara.

Bila Pasal 1 angka 15 UU Nomor 15 Tahun 2006 tentang Badan Pemeriksa Keuangan dan Pasal 1 angka 22 UU Nomor 1 Tahun 2004 tentang Perbendaharaan Negara dikaitkan dengan pendapat Lilik Mulyadi, berarti kerugian negara adalah ruginya negara yang besarnya sudah pasti sebagai akibat perbuatan melawan hukum, baik sengaja maupun lalai. Dengan demikian, kerugian negara hanya berkaitan dengan berkurangnya keuangan negara yang jumlahnya sudah pasti akibat perbuatan melawan hukum dan tidak ada kaitannya dengan uang pengganti.

Untuk menelaah lebih lanjut apakah ada hubungan antara uang pengganti dengan kerugian negara dalam konteks Pasal 18 ayat (1) huruf b UU Tipikor, perlu didalami pertanyaan apakah tepat dan adil menjatuhkan uang pengganti sebesar kerugian negara, atau apakah tepat kerugian negara disamakan dengan uang pengganti, sehingga dengan logika sederhana langsung mengadopsi besarnya kerugian negara sebagai besarnya uang pengganti yang harus dibayar terdakwa?

Dalam salah satu dakwaan Penuntut Umum dalam perkara tindak pidana korupsi di Pengadilan Tindak Pidana Korupsi pada Pengadilan Negeri Bandung, Penuntut Umum menyebutkan: "akibat perbuatan terdakwa, negara dirugikan sebesar Rp. 199.850.473,-. (seratus sembilan puluh sembilan juta delapan ratus lima puluh ribu empat ratus tujuh puluh tiga rupiah)". Terhadap dakwaan tersebut, setelah melalui proses pemeriksaan bukti dan saksi-saksi, Penuntut Umum dalam tuntutannya ${ }^{23}$ secara langsung menuntut terdakwa membayar uang pengganti sebesar kerugian negara tersebut tanpa mempertimbangkan keterangan saksisaksi yang menerangkan berapa sebenarnya jumlah harta yang diperoleh terdakwa dari kerugian negara tersebut.

Pertanyaan pertama, apa yang menjadi argumentasi Penuntut Umum sehingga menyimpulkan uang pengganti adalah sebesar kerugian negara, dan pertanyaan kedua, apakah tuntutan sedemikian tidak bertentangan dengan asas kepastian hukum 
dan asas keadilan?

Jika dicermati tuntutan Penuntut Umum yang secara langsung menyebutkan uang pengganti adalah sebesar kerugian negara, padahal telah diuraikan di atas bahwa uang pengganti sangat berbeda dengan kerugian negara, maka menurut penulis, Penuntut Umum telah melakukan kesalahan dalam menerapkan hukum. Dikatakan demikian karena penerapan "kerugian" tidak bisa dipandang sempit hanya dalam perspektif Pasal 1365 KUHPerdata, di mana tiap perbuatan yang melanggar hukum dan membawa kerugian kepada orang lain mewajibkan orang yang menimbulkan kerugian itu karena kesalahannya untuk mengganti kerugian tersebut, tetapi harus taat pada Pasal 18 ayat (1) huruf b UU Tipikor bahwa besarnya uang pengganti adalah sebesar harta benda yang telah "diperolehnya/dinikmatinya" dari tindak pidana korupsi.

Bila penerapan uang pengganti sebagaimana tuntutan Penuntut Umum tersebut dikaitkan dengan tujuan negara hukum serta perlindungan hak asasi terhadap yustisiabelen, maka membebankan kerugian negara sebagai uang pengganti bertentangan dengan pendapat Budiono Kusumohamidjojo yang mengatakan bahwa bila penyelenggaraan hukum tidak konsisten, maka berdampak pada masyarakat tidak lagi mengandalkan hukum sebagai perangkat kaidah yang mengatur kehidupan bersama; sebaliknya, bila konsisten dalam penyelenggaraan hukum, maka di situlah akan terjadi kepastian hukum.

Berdasarkan pendapat Budiono Kusumohamidjojo tersebut jelas bahwa penyelenggara negara (dalam hal ini Penuntut Umum) harus mengandalkan hukum dalam kehidupan bersama yang berarti harus mengedepankan nilai hukum yang terkandung dalam Pasal 18 ayat (1) huruf b UU Tipikor, yaitu bahwa pembayaran uang pengganti adalah sebesar uang yang dinikmatinya, bukan sebesar kerugian negara. Bila penerapan hukum dijalankan, masyarakat mengakui bahwa hukum yang diciptakan benar-benar dapat diandalkan demi terwujudnya kepastian hukum. Pendapat Budiono Kusumohamidjojo tersebut bersesuaian dengan pendapat
Sudikno Mertokusomo bahwa kepastian hukum dimaksudkan agar tercipta kehidupan yang lebih tertib di masyarakat, sehingga hukum harus bertugas menciptakan kepastian hukum, bukan justru sebaliknya.

Arief Sidharta mengemukakan bahwa asas kepastian hukum mengimplikasikan bahwa warga masyarakat harus bebas dari tindakan pemerintah dan pejabatnya yang sewenang-wenang. Pemerintah dan para pejabatnya harus terikat dan tunduk pada aturan hukum positif dan semua tindakan pemerintah serta para pejabatnya harus selalu bertumpu pada aturan hukum positif sebagai dasar hukumnya. Bila Penuntut Umum menyatakan besarnya uang pengganti diartikan sama dengan besarnya kerugian negara, maka menurut Arief Sidharta, sikap pemerintah dan pejabat yang demikian merupakan tindakan sewenang-wenang, tidak memberikan kepastian hukum dan keadilan bagi yustisiabelen, karena penerapan hukumnya telah menyimpang dari hukum positif dan hak asasi, sebagaimana diatur dalam Pasal 18 ayat (1) huruf b UU Tipikor.

Penerapan besarnya kerugian negara sebagai uang pengganti yang harus dibebankan kepada terdakwa dengan acuan Pasal 1365 KUHPerdata adalah kurang tepat, karena tidak mengkaitkannya dengan inti yang terkandung dalam Pasal 18 ayat (1) huruf $b$ UU Tipikor. Seharusnya Penuntut Umum menguraikan berapa sebenarnya keuntungan yang diperoleh terdakwa dari tindak pidana yang dilakukannya, bukan dengan cara sederhana dengan acuan Pasal 1365 KUHPerdata langsung menjustifikasi uang pengganti sebesar kerugian/ kerugian negara yang telah dihitung oleh BPK/BPKP. Oleh sebab itu, penerapan hukum yang dilakukan Penuntut Umum bahwa uang pengganti adalah sebesar kerugian negara telah menyimpang dari asas kepastian hukum dan keadilan, sebagaimana diatur dalam Pasal 18 ayat (1) hurufb UU Tipikor.

Perihal jumlah uang pengganti sebagaimana rumusan Pasal 18 ayat (1) huruf b UU Tipikor, ada pendapat tentang cara menghitungnya dengan acuan pembayaran uang tebusan yang berkaitan dengan gadai tanah, sebagaimana dalam Putusan Mahkmah Agung RI Nomor $26 \mathrm{~K} / \mathrm{Sip} / 1955$ tanggal 11 Mei 1955 dan Nomor 11 K/Sip/1957 tanggal 
15 Januari 1958, yaitu dengan cara negara dan terdakwa masing-masing memikul setengah dari perubahan nilai mata uang, diukur dari harga emas pada waktu tindak pidana korupsi dilakukan dan pada waktu pengadilan menjatuhkan putusannya. Bila negara, misalnya, menderita kerugian sebesar Rp. 60.000.000,- (enam puluh juta rupiah) dan harga emas pada waktu tindak pidana korupsi dilakukan Rp. 15.000 per gram, sedangkan harga emas pada saat putusan dijatuhkan Rp. 45.000,- per gram, maka uang pengganti yang harus dibayar terdakwa adalah $1 / 2 \mathrm{x} \mathrm{Rp}$. 45.000,-/Rp. 15.000,- x Rp.60.000.000,- = Rp. 90.000.000,-. (sembilan puluh juta rupiah) ${ }^{24}$

Penghitungan demikian menurut penulis tidak tepat, karena dengan cara demikian berarti telah menyamakan kerugian negara sebagai uang pengganti, padahal telah diuraikan di atas bahwa keduanya mempunyai pengertian yang berbeda. Cara yang tepat adalah kembali mengacu pada Pasal 18 ayat (1) huruf b UU Tipikor bahwa uang pengganti adalah sebesar uang yang "diperoleh atau dinikmati" terdakwa dari tindak pidana korupsi, di mana pembuktian tentang hal tersebut sepenuhnya merupakan tugas Penuntut Umum.

Dengan penerapan hukum yang demikian, asas kepastian hukum dan keadilan sebagai cita negara hukum yang bertujuan mewujudkan manusia Indonesia seutuhnya dan masyarakat Indonesia seluruhnya yang adil dan tertib serta perlindungan hak asasi berdasarkan Pancasila dan UUD 1945 tetap lestari, sehingga pada akhirnya yustisiabelen merasa puas (satisfaction) karena mendapatkan keadilan dan tidak dirugikan sebagai akibat kesalahan penerapan hukum.

\section{Simpulan}

Berdasarkan pembahasan di atas, maka dapat disimpulkan sebagai berikut:

1. Mengenai uang pengganti dan kerugian negara dapat dikemukakan hal-hal berikut:

a)Uang pengganti adalah uang yang dibayar terdakwa sebesar harta benda yang "diperoleh atau dinikmatinya" dari tindak pidana korupsi, bukan sebesar kerugian negara yang ditimbulkannya;

b) Besarnya uang pengganti wajib dibuktikan Penuntut Umum dalam persidangan, bukan secara sederhana langsung mendasarkannya pada besarnya kerugian negara, sebagaimana perhitungan BPK/BPKP dan acuan Pasal 1365 KUHPerdata;

c)Uang pengganti dimaksudkan untuk menarik kembali keuntungan yang diperoleh terdakwa dari tindak pidana yang dilakukannya, bukan untuk mengembalikan seluruh kerugian negara dan juga bukan untuk memulihkan seluruh kerugian negara;

d)Untuk membebankan uang pengganti kepada terdakwa tidak dikenal adanya penghukuman secara tanggung renteng; dan

e) Kerugian negara adalah kerugian atas barang milik negara yang nyata terjadi dan pasti jumlahnya sebagai akibat perbuatan melawan hukum, baik sengaja maupun lalai.

2. Penerapan hukum untuk menyatakan kerugian negara sebagai uang pengganti yang harus dibayar terdakwa tanpa didasarkan pada alat bukti adalah mencederai asas kepastian hukum dan keadilan serta hak asasi, dan merupakan kesalahan dalam penerapan hukum.

\section{Daftar Pustaka}

Hamzah Andi, 1994, Asas-asas Hukum Pidana, Edisi Revisi, Jakarta, Rineka Cipta.

Hiariej Eddy O.S., 2016, Eksistensi Komisi Pemberantasan Korupsi, Demi Keadilan, Antologi Hukum Pidana dan Sistem Peradilan Pidana, Jakarta, Pustaka Kemang.

Hiariej Eddy O.S, "Menyoal Putusan Pengadilan Tipikor", Jurnal MasalahMasalah Hukum, Vol. 42, No. 1, Januari 2013.

Huda Chairul, "Menyoal Pidana Tambahan "Pembayaran Uang Pengganti" Dalam

\footnotetext{
24.R. Wiyono, 2008, Pembahasan Undang-undang Pemberantasan Tindak Pidana Korupsi, Edisi Kedua, Jakarta, Sinar Grafika, hlm.147.
} 
Perkara Korupsi”, tersedia di website $\mathrm{h} \mathrm{t} \mathrm{t} \mathrm{p}: / / \mathrm{h}$ u d a chairulhudashmh.blogspot.com, diakses pada tanggal 10 Juni 2015 ,

Kamil Iskandar, 25 April 2008, Ceramah pada Pelatihan Hakim Tipikor Angkatan II, Ciloto, Bogor.

Kusumohamidjojo Budiono, 1999, Ketertiban Yang Adil, Problematik Filsafat Hukum, Jakarta, Grasindo.

Manan Bagir, 2015, Sistem Peradilan Berwibawa (Suatu Pencarian), Jakarta, MahkamahAgung RI.

Mariadi, Salman, 16 April 2008, Ceramah pada Pelatihan Hakim Tipikor Angkatan II, Ciloto, Bogor.

Mulyadi Lilik, 2007, Tindak Pidana Korupsi di Indonesia, Normatif, Teoritis, Praktik dan Masalahnya, Bandung, Alumni.

Munzil, Fontian, Imas Rosidawati Wr, dan Sukendar, "Kesebandingan Pidana Uang Pengganti dan Pengganti Pidana Uang Pengganti dalam Rangka Melindungi Hak Ekonomis Negara dan Kepastian Hukum", Jurnal Hukum IUS QUIA IUSTUM, Vol. 22, No.1, Januari 2015.

Priyatno Dwidja, 2012, Kriminalisasi Kebijakan, Wajah Hukum Pidana, Asas dan Perkembangannya, Jakarta, Gramata.

Rifai Ahmad, 2010, Penemuan Hukum oleh Hakim dalam Perspektif Hukum Progresif, Jakarta, Sinar Grafika.

Sapardjaja Komariah Emong, 15 April 2008, Ceramah pada Pelatihan Hakim Tipikor Angkatan II, Ciloto, Bogor.

Setiabudhi I.K. Rai, 2016, Peran Masyarakat Sipil dalam Pemberantasan Korupsi : Model Pencegahan dari Bali, Demi Keadilan, Antologi Hukum Pidana dan Sistem Peradilan Pidana, Jakarta, Pustaka Kemang.

Sidharta Bernard Arief, 2000, Refleksi Tentang Struktur Ilmu Hukum, Sebuah penelitian tentang fundasi kefilsafatan dan sifat keilmuan Ilmu Hukum sebagai landasan pengembangan Ilmu Hukum Nasional Indonesia, Bandung, Mandar Maju.

Thohari A. Ahsin, "Dari Law Enforcement ke Justice Enforcement", Harian KOMPAS, 3 Juli 2002.
Wiyono R., 2008, Pembahasan Undangundang Pemberantasan Tindak Pidana Korupsi, Jakarta, Sinar Grafika.

Kitab Undang-Undang Hukum Pidana (KUHP).

Kitab Undang-Undang Hukum Perdata (KUH Perdata).

Undang-Undang Nomor 31 Tahun 1999 tentang Pemberantasan Tindak Pidana Korupsi jo. Undang-Undang Nomor 20 Tahun 2001 tentang Perubahan atas Undang-Undang Nomor 31 Tahun 1999 tentang Pemberantasan Tindak Pidana Korupsi.

Undang-Undang Nomor 17 Tahun 2003 tentang Keuangan Negara.

Undang-Undang Nomor 1 Tahun 2004 tentang Perbendaharaan Negara. 